\title{
Evaluasi Ketidakcocokan Ukuran Kursi Kuliah pada Perguruan Tinggi
}

\author{
(Evaluation of the Mismatch of Lecture Chair Size in Higher Education) \\ Rela Adi Himarosa ${ }^{a}$ \\ ${ }^{a}$ Program Studi Teknik Mesin, Fakultas Teknik, Universitas Muhammadiyah Yogyakarta \\ Jalan Brawijaya, Tamantirto, Kasihan, Bantul, DI Yogyakarta, Indonesia, 55183 \\ e-mail: rela.himarosa@umy.ac.id
}

\begin{abstract}
Abstrak
Furnitur ruang kuliah merupakan salah satu sarana fisik penunjang pembelajaran. Kesehatan manusia saat duduk sangat dipengaruhi oleh furnitur seperti meja dan kursi yang digunakan. Aktivitas mahasiswa di perguruan tinggi banyak di kelas dengan posisi duduk statis. Duduk dalam waktu yang lama merupakan salah satu faktor yang mampu menyebabkan gangguan muskuloskeletal terutama pada bagian punggung bawah. Gejala gangguan muskuloskeletal pada remaja menjadi faktor risiko yang signifikan untuk terjadinya gangguan muskuloskeletal saat dewasa. Hasil antropometri menunjukkan ketidakcocokan dimensi furnitur yang digunakan sehingga menimbulkan rasa tidak nyaman, sakit anggota badan, dan terjadinya gangguan pada muskuloskeletal. Posisi berdiri dan duduk yang benar menjadi faktor penting untuk pencegahan masalah ini. Hasil dari penelitian ini menunjukkan ketidakcocokan antara ukuran antropometri mahasiswa dan desain kursi yang digunakan di universitas untuk proses pembelajaran. Data antropometri diambil dari ukuran 80 mahasiswa dengan sebaran $50 \%$ pria dan $50 \%$ wanita. Tiga model kursi perkuliahan dijadikan evaluasi ketidakcocokan. Model kursi 1 merupakan kursi model lama yang sudah tidak dipakai, model kursi 2 merupakan kursi yang sudah mulai digantikan, terakhir kursi model 3 merupakan kursi terbaru yang digunakan di perkuliahan. Ketiga model kursi yang ada di sebuah perguruan tinggi memiliki variasi ketidakcocokan dengan antropometri mahasiswa. Model kursi 3 produksi terbaru memiliki 100\% ketidakcocokan pada tinggi meja dan sebesar $50 \%$ pada tinggi kursi. Model kursi 1 produksi lama memiliki 100\% ketidakcocokan pada kedalaman kursi. Hasil evaluasi ini mampu menunjukkan model kursi yang memiliki tingkat ketidakcocokan paling kecil sehingga pemilihan model kursi terbaru harus mempertimbangkan data antropometri.
\end{abstract}

Kata kunci: Ketidakcocokan, Muskuloskeletal, Antropometri, Ergonomi

\begin{abstract}
Furniture at class, is one of the physical property to support the learning process. Human health is greatly influenced by furniture such as tables and chairs used when they are sitting. Student activities in university mostly done at class with static sitting positions. Sitting in a long time is one of the factors that cause musculoskeletal disorders, especially in the lower back. The symptoms of musculoskeletal disorders in adolescents is a significant risk factor for the occurrence of musculoskeletal disorders in adulthood. Anthropometric results can show a mismatch of dimensions of the furniture used, which results in discomfort, limb pain, and the occurrence of musculoskeletal disorders. Correct standing and sitting position is an important factor for the prevention of this problem. The results of this study indicate a mismatch between the anthropometric size of students and the design of chairs used at universities for the learning process. Anthropometric data was taken from 80 students with a distribution of $50 \%$ male and $50 \%$ female. Three lecture chair models were used as an mismatch evaluation. First chair model was the old model chair that is not used anymore, second chair model is a chair that has begun to be replaced, the last chair model is the latest seat used in university. The three chair models available at a
\end{abstract}


university have variations in mismatch with student anthropometry. The latest production chair model no 3 has a 100\% mismatch at table height and at 50\% at chair height. Old production, the chair no 1 models have $100 \%$ mismatch in chair depth. The results of this evaluation were able to show the chair model that has the smallest degree of mismatch, so the selection of the next chair model must consider anthropometric data.

Keywords: Mismatch, Musculoskeletal, Anthropometry, Ergonomic

\section{Pendahuluan}

Antropometri merupakan pengukuran karakteristik tubuh, seperti panjang segmen tubuh, lebar, dan tinggi. Data antropometri dapat digunakan untuk desain alat, stasiun kerja, dan pakaian [1]. Aktivitas di industri, kantor, sekolah, hingga kampus mengharuskan tetap dalam posisi tertentu, seperti duduk terus menerus dan melakukan pekerjaan yang monoton. Aktivitas tersebut mengakibatkan ketidaknyamanan fisik, gangguan muskuloskeletal (musculoskeletal disorder/ MSD) akibat postur posisi yang buruk [2].

Evaluasi ketidakcocokan desain kursi dilakukan pada bagian tinggi kursi (seat height/ $\mathrm{SH})$, kedalaman kursi (seat depth/ SD), tinggi sandaran (backrest height/ $\mathrm{BH}$ ), dan sudut sandaran (backrest angle). Tinggi kursi (SH) merupakan jarak dari tanah ke bagian tempat duduk. Kursi yang didesain terlalu tinggi akan meregangkan otot-otot kaki karena kehilangan kontak dengan tanah. Hal ini mengakibatkan rasa kaku dan sakit. Ketinggian kursi harus dirancang agar lebih tinggi dari panjang betis. Kedalaman Kursi (SD) merupakan jarak horisontal dari bagian belakang permukaan duduk kursi sampai depan. Kedalaman ini dihitung dari kedalaman buttock-politeal depth. Seharusnya, ada ruang antara bagian ujung depan kursi dengan bagian belakang lutut. Tinggi sandaran $(\mathrm{BH})$ merupakan jarak vertikal dari sisi atas permukaan dudukan kursi ke titik tertinggi sandaran. Tinggi sandaran disesuaikan dari ketinggian bahu. Sudut dan tinggi sandaran (backrest angle \& height) juga berpengaruh terhadap kenyaman. Kecenderungan seseorang duduk dan bersandar memiliki variasi yang bergantung pada kondisi kerja. Kursi di dalam bus dirancang 110 derajat, desain 95-100 derajat untuk kursi mahasiswa, 110-125 derajat untuk kursi istirahat, dan memiliki tinggi sandaran yang sesuai.

Diperkirakan $70-85 \%$ orang mengalami sakit punggung bagian bawah (low back pain/ LBP) selama hidup mereka [3]. LBP diperkirakan terjadi pada usia rata-rata 30 dan memuncak pada usia antara 45-60 tahun. Sakit punggung bawah (LBP) disebabkan gangguan muskoloskeletal (MSD) yang merupakan dampak dari duduk dalam waktu lama [4]. Duduk dalam posisi statis akan meningkatkan tekanan pada otot punggung dan bantalan tulang belakang (spinal disc) [2]. Penggunaan furnitur yang dirancang dengan tepat dapat mengurangi kelelahan dan ketidaknyamanan pada posisi duduk. Pengukuran antropometri merupakan pertimbangan penting dalam mendesain furnitur yang ergonomis dan sesuai data antropometri mahasiswa [5].

Perhatian pada desain furnitur di universitas belum banyak dikarenakan penelitian furnitur ergonomis saat usia kanak-kanak lebih berpengaruh terhadap tumbuh kembang dibanding pada masa dewasa [6]. Kebiasaan duduk yang terbentuk di usia muda akan sulit diubah saat usia dewasa [7]. Meskipun demikian, keragaman suku dan ras yang ada di Indonesia berkumpul saat menjalani pembelajaran di pendidikan tinggi. Oleh karena itu, penelitian ini dilakukan untuk menyelidiki ketidakcocokan antara fitur furnitur pembelajaran di universitas berupa kursi yang menyatu dengan meja yang memiliki tiga model berbeda dengan dimensi tubuh mahasiswa.

\section{Metode}

\subsection{Furnitur kursi mahasiswa}

Furnitur kursi yang digunakan perkuliahan ditunjukkan Gambar 2.1. Dipilih tiga model kursi dengan desain yang berbeda. Peneliti menggunakan satu sampel kursi masing-masing model untuk dilakukan pengukuran, diukur sebanyak tiga kali untuk memastikan hasil ukuran. Model kursi 1 merupakan jenis kursi model paling lama digunakan sebelum tahun 2000 (Gambar 2.1a), kursi 2.1b kursi yang digunakan sejak 2007, dan kursi 2.1c merupakan 
model terbaru kursi kuliah digunakan mulai tahun 2018. Desain kursi mengalami beberapa perubahan dimensi dan fungsi. Data ukuran kursi ditunjukkan oleh Tabel 2.1.

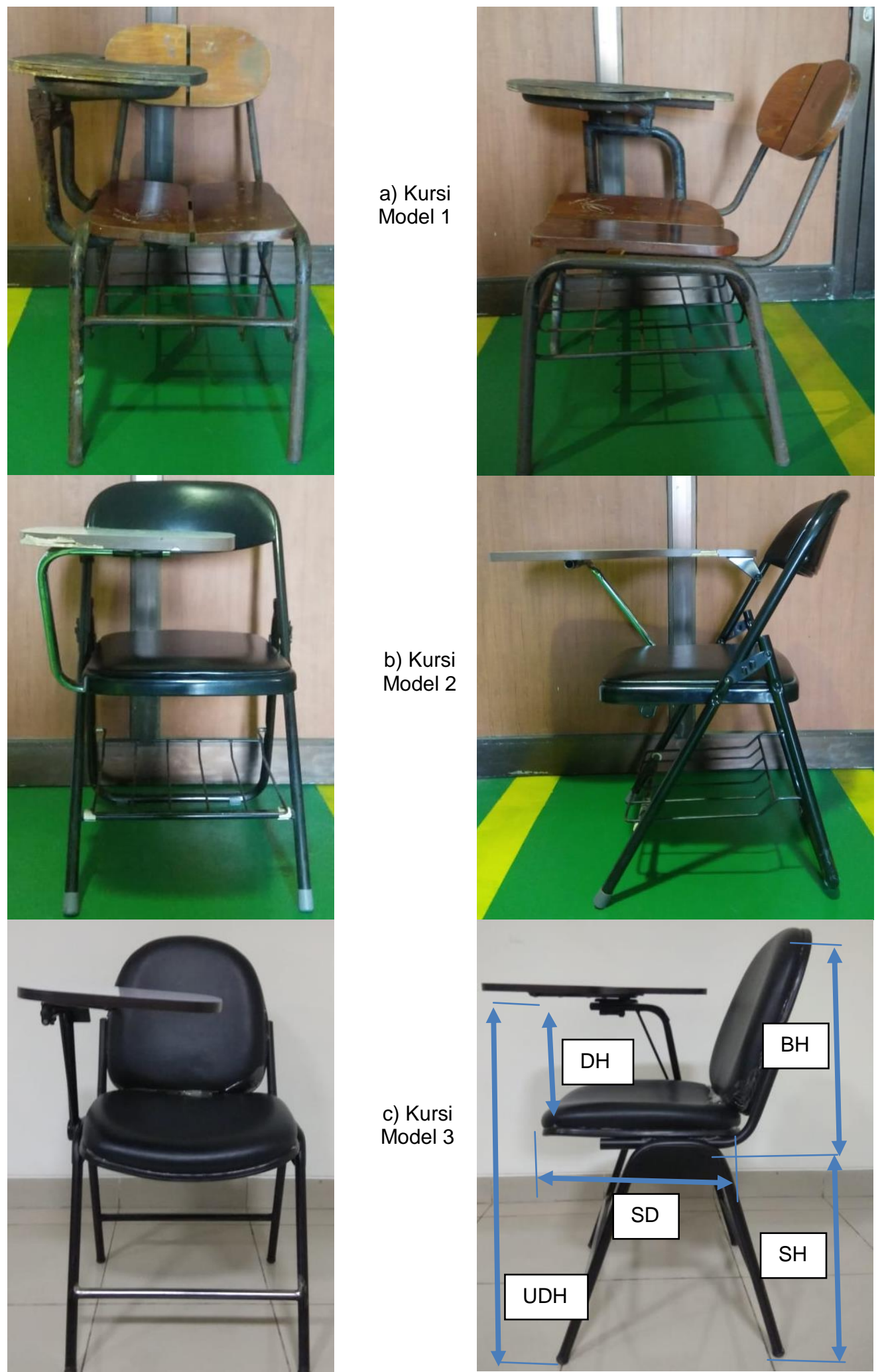

Gambar 2.1. Bentuk model kursi universitas (a) kursi model 1, (b) kursi model 2, (c) kursi model 3 


\begin{tabular}{cccccc}
\multicolumn{7}{c}{ Tabel 2.1. Data ukuran desain kursi } \\
\hline Model Kursi & DH & UDH & SD & BH & S \\
\hline 1 & 27 & 67 & 55 & 35 & 4 \\
2 & 23 & 61 & 45 & 35 & 43 \\
3 & 26 & 74,5 & 45 & 39 & 45 \\
Keterangan & & & SD & : seat depth \\
DH & : desk height & BH & : backrest height \\
UDH & : under-surface height & SH & : seat height
\end{tabular}

$\begin{array}{cc}\text { Huruf } & \text { Bagian Tubuh } \\ \text { A } & \text { Tinggi sampai bahu } \\ \text { B } & \text { Tinggi siku duduk } \\ \text { C } & \text { Panjang buttock-popliteal } \\ \text { D } & \text { Ketinggian popliteal } \\ \text { E } & \text { Ketinggian lutut }\end{array}$

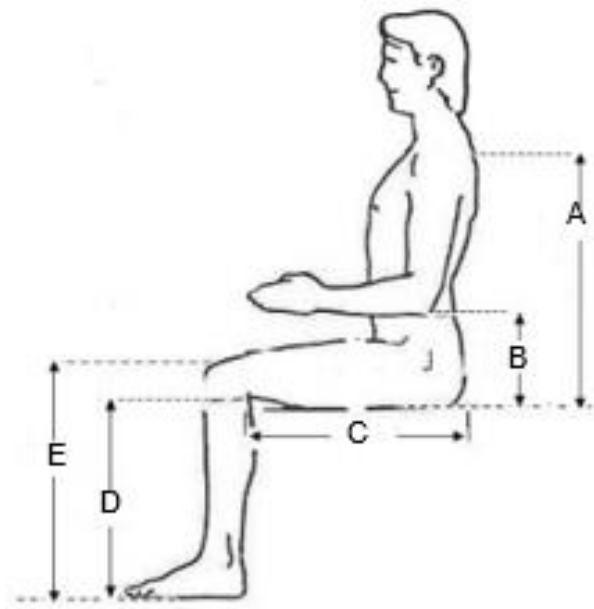

Gambar 2.2. Bagian karakteristik tubuh yang diukur

\subsection{Pengukuran antropometri}

Sampel yang diukur berjumlah 80 mahasiswa volunter, dengan rentang usia 18-25 tahun dan rata-rata usia 21 tahun. Pembagian proporsi yaitu 40 putra dan 40 putri. Sebaran asal mahasiswa yaitu dari Sumatera, Jawa, Kalimantan, Sulawesi, dan Papua. Data antropometri ditunjukkan pada Tabel 1. Pengukuran dilakukan di laboratorium desain dengan perlengkapan penunjang data antropometri.

Tabel 2.2. Hasil antropometri (cm)

\begin{tabular}{cccccc}
\hline Data & A & B & C & D & E \\
Antropometri & 72 & 28 & 54 & 52 & 59 \\
Max & 51 & 17 & 37 & 33 & 41 \\
Min & 59 & 23 & 45 & 42 & 51 \\
Mean & 2,49 & 3,48 & 3,97 & 4,55 \\
Standar Deviasi & 5,14 & 23 & 45 & 43 & 51 \\
Percentil 5\% & 59 & 50,1 & 48 & 57 \\
Percentil 95\% & 68,1 & 26,1 & 50,1 &
\end{tabular}

\subsection{Perhitungan hubungan dimensi furnitur dengan dimensi tubuh}

Data antropometri yang digunakan sebagai dasar pembuatan desain furnitur berdasarkan pada prinsip ergonomi. Data tersebut digunakan untuk mendefinisikan rentang ukuran dimensi furnitur yang sesuai.

\section{a. Tinggi kursi (Seat height)}

Tinggi kursi harus disesuaikan dengan dimensi popliteal, lutut harus bisa ditekuk membentuk sudut $30^{\circ}$ relatif terhadap sumbu vertikal [8]. Ketidakcocokan tinggi kursi dirumuskan dalam persamaan (1) [6].

$$
(\mathrm{D}+2) \cos 30^{\circ} \leq \mathrm{SH}<(\mathrm{D}+2) \cos 5^{\circ}
$$


b. Kedalaman kursi (Seat depth)

Kedalaman kursi dirancang untuk persentil ke 5 dari ukuran popliteal-buttock. Kedalaman kursi setidaknya $5 \mathrm{~cm}$ lebih pendek dari popliteal-buttock. Persamaan ketidakcocokan dirumuskan dalam persamaan (2) [6].

$$
80 \% \mathrm{C} \leq \mathrm{SD}<95 \% \mathrm{C}
$$

c. Tinggi sandaran (Backrest height)

Tinggi sandaran yang sesuai adalah ketika di bawah tulang belikat (scapula) untuk memudahkan pergerakan dari lengan dan bagian tubuh. Oleh karenanya, disesuaikan bahwa tinggi sandaran masih di bawah tulang belikat, dirumuskan dengan persamaan (3) [9].

$$
60 \% \mathrm{~A} \leq \mathrm{BH}<80 \% \mathrm{~A}
$$

d. Tinggi meja (Desk height)

Ketinggian siku dianggap sebagai penentu utama dari tinggi meja. Beban yang diterima dari tulang belakang akan berkurang secara signifikan saat lengan menahan beban tersebut di atas meja. Hubungan antara ukuran tubuh dan penentuan tinggi meja dirumuskan dalam persamaan (4) [9].

$$
B+(D+2) \cos (30) \leq D H<(D+2) \cos (5)+0,8517 B+0,1483 A
$$

e. Ketinggian kolong meja (Under-surface of desk height)

Ketinggian ini diperlukan untuk ruang antara lutut dan meja. Ukuran ruang tersebut harus mampu memenuhi saat lutut disilangkan dibawah meja. Hubungan persamaan untuk menentukan dimensi kolong bawah meja dirumuskan pada persamaan (5) [9].

$$
(E+2)+2 \leq U D H
$$

\section{Hasil dan Pembahasan}

\subsection{Ketidakcocokan furnitur}

Dari ketiga model kursi universitas yang dijadikan objek penelitian, data antropometri didapatkan kesesuaian ukuran dimensi tubuh antropometri terhadap dimensi desain furnitur yang ditunjukkan Tabel 3.1.

Tabel 3.1. Perhitungan desain kursi yang sesuai

\begin{tabular}{cccccc} 
Bagian Tubuh & Batas Atas & $\begin{array}{c}\text { Batas } \\
\text { Bawah }\end{array}$ & $\begin{array}{c}\text { Ukuran } \\
\text { Kursi }\end{array}$ & $\begin{array}{c}\text { Model } \\
\text { Kursi }\end{array}$ & $\begin{array}{c}\text { Bagian } \\
\text { Kursi }\end{array}$ \\
\hline \multirow{3}{*}{ Popliteal height } & 45,33 & 39,15 & 41 & Model 1 & Tinggi \\
& 47,64 & 41,16 & 43 & Model 2 & Kursi \\
\hline Buttock- & 49,95 & 43,17 & 45 & Model 3 & \\
popliteal length & 58,75 & 57,89 & 55 & Model 1 & Kedalaman \\
& 56,25 & 47,36 & 45 & Model 2 & Kursi \\
\hline \multirow{3}{*}{ Shoulder height } & 58,33 & 47,36 & 45 & Model 3 & \\
& 58,33 & 43,75 & 35 & Model 1 & Tinggi \\
& 65 & 43,75 & 35 & Model 2 & Sandaran \\
\hline \multirow{2}{*}{ Knee height } & 63 & - & 67 & Model 1 & Tinggi \\
& 57 & - & 61 & Model 2 & Kolong \\
Elbow-seat & 70,5 & - & 74,5 & Model 3 & Meja \\
height & 30,61 & 20,28 & 68 & Model 1 & Tinggi \\
& 28,61 & 21,15 & 66 & Model 2 & Meja \\
\hline
\end{tabular}


Dimensi kesesuaian ukuran tubuh untuk setiap dimensi desain furnitur di universitas menjadi batas kecocokan furnitur terhadap populasi mahasiswa pengguna furnitur kursi tersebut. Kecocokan setiap model kursi disesuaikan dalam rentang ukuran tubuh batas atas dan batas bawah. Hal ini dapat disimpulkan bahwa kecocokan populasi mahasiswa terhadap dimensi furnitur yang terdapat di universitas ditunjukkan pada Tabel 3.2.

Tabel 3.2. menunjukkan ketidakcocokan yang terjadi antara populasi mahasiswa dengan desain furnitur universitas. Sebaran populasi dan batas desain yang disarankan digambarkan pada Gambar 3.1 (a-c) tampak bahwa model 3 yang merupakan kursi model terbaru justru memiliki persentase ketidakcocokan paling besar yaitu $50 \%$ terhadap desain ketinggian kursi. Ketidakcocokan ketinggian kursi dapat menyebabkan ketidaknyamanan karena harus meletakkan pantat lebih ke depan saat membaca dan menulis. Hal ini mengakibatkan kurangnya dukungan punggung dalam posisi ini yang menyebabkan terjadinya postur bungkuk (kifosis) yaitu lengkungan tulang belakang yang membuat punggung bagian atas terlihat membulat [1].

Dengan desain yang tidak sesuai, gaya yang diterima otot akan lebih besar untuk menjaga stabilitas dan keseimbangan. Hal ini mampu menyebabkan kelelahan dan ketidaknyamanan dan menyebabkan timbul kebiasaan perilaku sikap postur tubuh yang buruk hingga berdampak pada nyeri leher dan punggung.

Desain kesesuaian kedalaman kursi SD (seat depth) ditunjukkan pada Gambar 3.2 (a,b) furnitur model 2 dan 3 yang memliki dimensi ukuran yang sama. Banyak populasi keluar dari batas bawah pada hasil sebaran dimensi panjang buttock-popliteal terhadap desain kursi model 1. Ukuran kedalaman kursi yang tidak sesuai mengakibatkan meningkatkan ketegangan otot pada bagian paha [9]. Hal ini juga akan mengurangi penggunaan dukungan tubuh bagian bawah yang membantu dalam mendistribusikan dan mengurangi beban pada pantat dan paha yang menyebabkan pengguna merasakan sensasi terjatuh [6].

Gambar 3.3 (a,b) menunjukkan sebaran populasi terhadap sandaran kursi. Model furnitur kursi 1 dan 2 dengan dimensi yang sama memiliki ketidakcocokan sebesar 51,25\% sedangkan ketidakcocokan paling kecil didapatkan di model 3 sebesar 11,25\%. Sandaran kursi BH (backrest height) berfungsi untuk menghindari terjadinya nyeri punggung. Ketidakcocokan pada sandaran memliki konsekuensi yang menyebabkan gangguan postur tubuh [6]. Desain sandaran harus memperhatikan kondisi saat menulis, jika mengambil batas atas mahasiswa yang lebih pendek sehingga akan cepat lelah, dan jika diambil batas bawah mahasiswa yang lebih tinggi, kondisi tersebut akan berdampak pada sakit punggung bawah [10].

Tabel 3.2. Ketidakcocokan desain dimensi furnitur terhadap ukuran tubuh mahasiswa

\begin{tabular}{cccccc}
\hline Model & $\begin{array}{c}\text { Tinggi } \\
\text { kursi } \\
(\%)\end{array}$ & $\begin{array}{c}\text { Kedalaman } \\
\text { kursi } \\
(\%)\end{array}$ & $\begin{array}{c}\text { Tinggi } \\
\text { sandaran } \\
(\%)\end{array}$ & $\begin{array}{c}\text { Tinggi } \\
\text { kolong } \\
\text { kursi (\%) }\end{array}$ & $\begin{array}{c}\text { Tinggi } \\
\text { meja } \\
(\%)\end{array}$ \\
\hline $\mathbf{1}$ & 43,75 & 100 & 51,25 & 0 & 16,25 \\
$\mathbf{2}$ & 42,5 & 75 & 51,25 & 6,25 & 21,25 \\
$\mathbf{3}$ & 50 & 75 & 11,25 & 0 & 100 \\
\hline
\end{tabular}




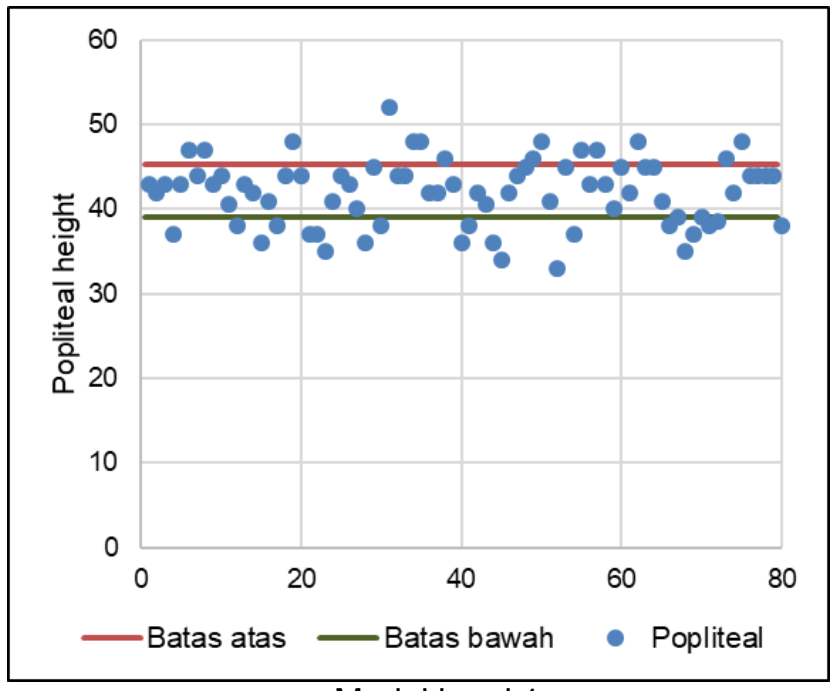

a. Model kursi 1

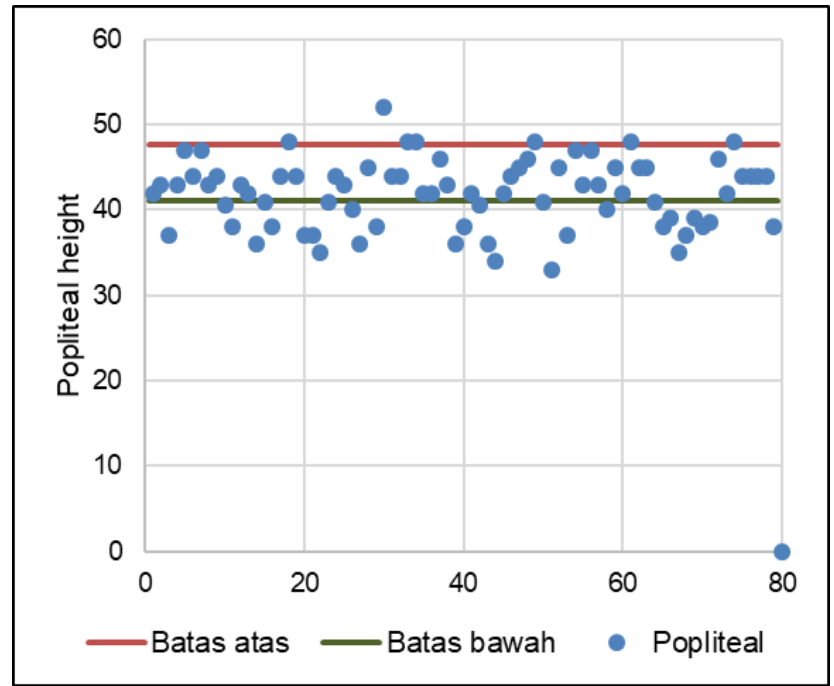

b. Model kursi 2

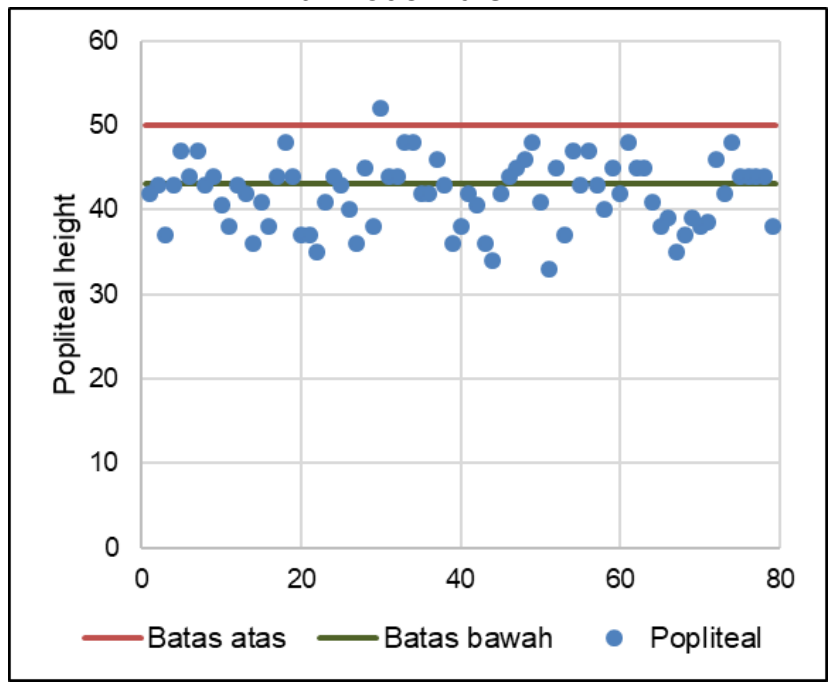

c. Model kursi 3

Gambar 3.1. Sebaran ketidakcocokan antropometri mahasiswa terhadap desain ketinggian kursi (a) model 1, (b) model 2, (c) model 3 


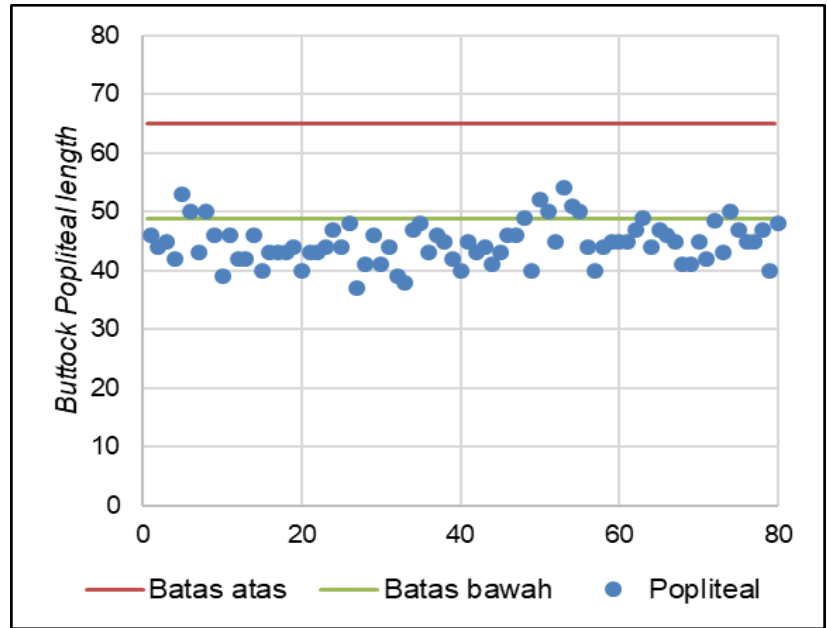

a. Model 1

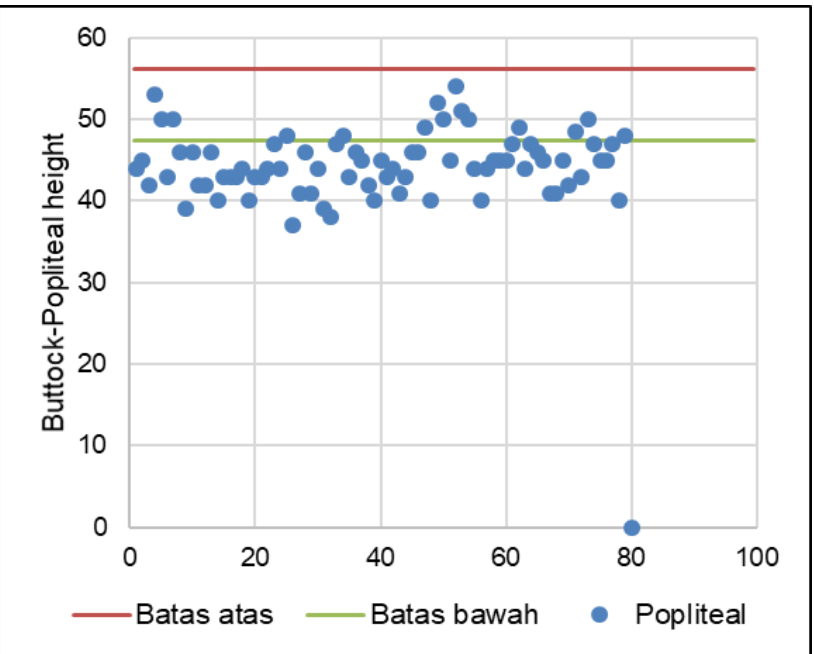

b. Model 2 dan 3

Gambar 3.2. Sebaran ketidakcocokan desain kedalaman kursi seat depth (SH), a) ketidakcocokan kedalaman kursi pada desain model kursi 1, b) ketidakcocokan kedalaman kursi pada desain model kursi 2 dan 3 yang memiliki ukuran kedalaman kursi sama

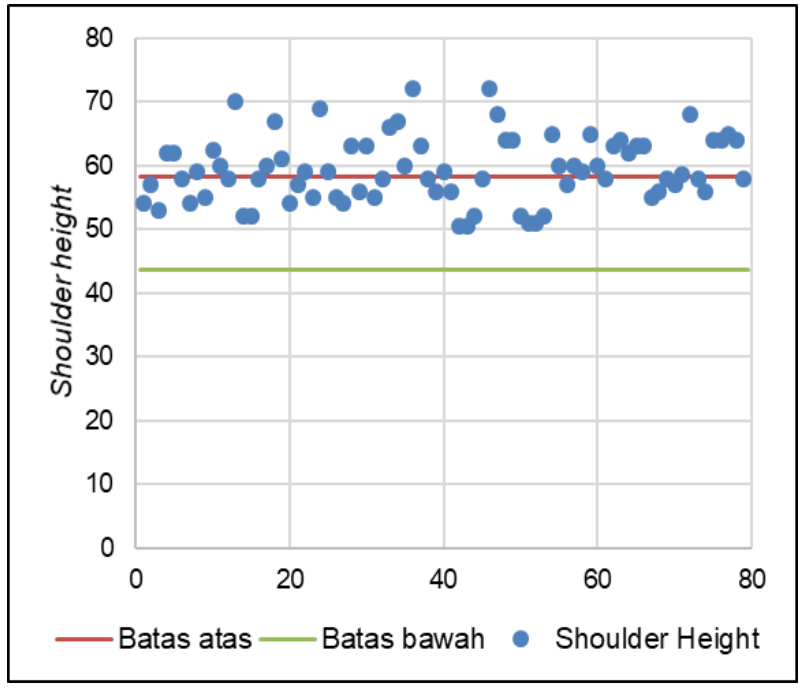

a. Model 1 dan 2 


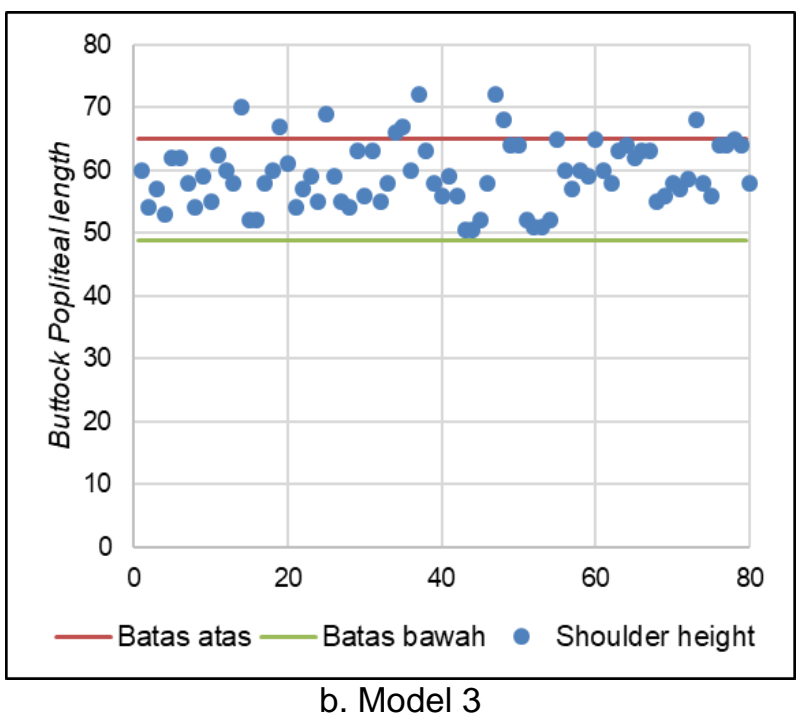

Gambar 3.3. Sebaran mahasiswa terhadap batas desain ketinggian sandaran kursi/ backrest height $(B H)$, a) ketidakcocokan ketinggian sandaran pada desain model kursi 1 dan 2 yang memiliki ukuran sama, b) ketidakcocokan ketinggian sandaran pada desain model kursi 3

\section{Kesimpulan}

Hasil data antropometri mahasiswa menunjukkan bahwa ketidakcocokan ditemukan disemua model kursi. Perubahan model kursi dari yang paling lama dan yang terbaru tidak mampu mencegah ketidakcocokan desain furnitur kursi dengan karakteristik antropometri mahasiswa di universitas. Desain kursi terbaru sangat bagus kesesuaian untuk sandaran kursi, tetapi memiliki ketidakcocoan yang besar untuk desain tinggi meja. Furnitur penunjang pendidikan di universitas harus mendukung kegiatan belajar mahasiswa. Oleh karena itu, harus memfasilitasi kegiatan pembelajaran dengan menyediakan kursi yang nyaman dan mampu mengurangi ketegangan pada otot tubuh. Temuan ini mampu menjadikan dasar untuk pembuatan desain furnitur kursi yang cocok dengan karakteristik mahasiswa pengguna. Desain kursi yang lebih ergonomis dapat membantu mencegah ketidaknyamanan, dan menghindari mahasiswa mengalami gangguan postur akibat duduk dalam waktu lama dengan posisi yang tidak wajar.

\section{Daftar Pustaka}

[1] G. Panagiotopoulou, K. Christoulas, A. Papanckolaou, and K. Mandroukas, "Classroom furniture dimensions and anthropometric measures in primary school," Appl. Ergon., vol. 35, no. 2, pp. 121-128, 2004.

[2] R. M. Farooqui and R. B. Shahu, "Analysis of anthropometric dimensions for sitting posture and chair design: a review," Int. J. Innov. Eng. Technol., vol. 6, no. 3, pp. 221224, 2016.

[3] G. B. J. Andersson, "Epidemiological features of chronic low-back pain," The Lancet, vol. 354, no. 9178, pp. 581-585, 1999.

[4] M. L. Magnusson and M. H. Pope, "a review of the biomechanics and epidemiology of working postures," J. Sound Vib., vol. 215, no. 4, pp. 965-976, 1998.

[5] J. V Reddy, "Evaluation of library furniture and anthropometric characteristics of St. Mary's students for ergonomics design of table and chair," Int. J. Res. Stud. Sci. Eng. Technol., vol. 2, no. 5, pp. 27-32, 2015.

[6] C. Parcells, M. Stommel, and R. P. Hubbard, "Mismatch of classroom furniture and student body dimensions: empirical findings and health implications," J. Adolesc. Heal., vol. 24, no. 4, pp. 265-273, 1999.

[7] S. Baharampour, J. Nazari, I. Dianat, and M. Asgharijafarabadi, "Student's body 
dimensions in relation to classroom furniture," Heal. Promot. Perspect., vol. 3, no. 2, pp. 165-174, 2013.

[8] J. F. M. Molenbroek, Y. M. T. Kroon-Ramaekers, and C. J. Snijders, "Revision of the design of a standard for the dimensions of school furniture," Ergonomics, vol. 46, no. 7, pp. 681-694, 2003.

[9] S. R. Agha, "School furniture match to students' anthropometry in the Gaza Strip," Ergonomics, vol. 53, no. 3, pp. 344-354, 37-41, 2010.

[10] E. Kahya, "Evaluation of the classroom furniture for university students," J. Eng. Archit. Fac. Eskisehir Osmangazi Univ., vol. 26, no. 1, pp. 20-29, 2018. 